\title{
Outward FDI, location choices and innovation performance of emerging market
} enterprises

\begin{abstract}
Although prior research conceptualizes how knowledge-seeking motivates the internationalization of emerging-market enterprises (EMEs), whether outward foreign direct investment (OFDI) indeed leads to enhanced innovation performance has received limited attention. We address this subject by conceptualizing how Chinese EMEs' OFDI enhances their subsidiaries' organizational learning and innovation performance and whether geographic location choices influence this relationship. Our panel data analysis of Chinese EMEs shows that OFDI has a positive effect on innovation performance of Chinese EMEs' subsidiaries and that this effect is stronger when the OFDI is directed towards developed rather than emerging countries. These findings advance the notion that EMEs can use OFDI as a strategy to globalize $R \& D$ and enhance their innovation performance and demonstrate that certain established assumptions regarding organizational learning are not valid for EMEs.
\end{abstract}

Keywords: Outward Foreign Direct Investment; Innovation; Organizational Learning; Geographic Location; Subsidiaries; Emerging Market Enterprises; China 


\section{Introduction}

The past two decades have witnessed a remarkable rise in outward foreign direct investment (OFDI) and rapid advancements in technological innovation from emerging market enterprises (EMEs) (Hoskisson et al., 2013; Luo et al., 2011). Innovation scholars have sought to explain this phenomenon by examining how emerging countries enhance indigenous $R \& D$ capabilities by reforming their national innovation systems to enable more market-based competition and by encouraging technological advancement through internationalization activities (e.g., Liu et al., 2011; Wu et al., 2016). In particular, scholarly research considers that OFDI is a key mechanism through which technological laggards seek to learn and develop technological capabilities on a global basis (Cantwell, 1989).

Despite the consensus that internationalization generates learning opportunities for firms, the assumptions and findings that have informed theory are largely based on studies of internationalized firms from developed economies. As a result, we have an incomplete understanding of whether EMEs -as latecomers- can successfully learn and absorb new knowledge from abroad (Chittoor et al., 2015). The theoretical significance of this question derives from the understanding of the drivers of EMEs' technological advantages and their unique approaches to learning, particularly through internationalization. From an organizational learning perspective, firms from advanced economies typically develop technological advantages by relying on internal R\&D and cumulative experiential learning (Teece, 1986). However, pathdependency, strong government involvement and underdeveloped institutions in emerging economies make it difficult for EMEs to adopt such learning models. By studying whether and when OFDI helps to improve EMEs' innovation performance, this study contributes to the literature on innovation and internationalization of EMEs in two ways. 
First, although prior research suggests that EMEs use internationalization as a learning tool to upgrade innovation capabilities (Guillen and Garcia-Canal, 2009), the intersection of OFDI strategies, organizational learning and innovation is under-theorized (Hotho et al., 2015). Our contribution consists primarily in demonstrating whether and when OFDI helps EMEs' subsidiaries enhance their innovation performance by conceptualizing how they can learn and integrate knowledge from foreign locations and use it for innovation. Second, building on the notion that not all location choices are equally beneficial to all EMEs, we conceptualize how geographic destination choices of OFDI (developed vs. emerging countries) facilitate or constrain the proposed innovation-enhancing effects of OFDI by influencing subsidiaries' organizational learning in the host countries. This approach enables us to extend beyond merely asking the question of whether OFDI enhances the innovation performance of EMEs' subsidiaries and instead spurs us to theorize regarding how different OFDI location strategies can lead to differential innovation performance outcomes for EMEs.

China is a particularly suitable empirical setting for this study. On the one hand, many Chinese firms have in recent years accelerated globalization of innovation by engaging in OFDI (WIR, 2014) and, on the other, these firms have leapfrogged others to become important competitors in the global battle for technological leadership. We test our predictions by investigating 96 publicly listed high-technology Chinese manufacturing enterprises, which have conducted OFDI by establishing a total of 247 subsidiaries in 46 different counties over the period of 2001-2012. Our findings explain the rise of EMEs as innovators by demonstrating how OFDI positively influences the innovation success of EMEs' subsidiaries and how location choices influence this relationship. 


\section{Theoretical framework and review of China's innovation and OFDI evolution}

\subsection{EMEs' international learning and innovation}

Organizational learning refers to the change in an organization's knowledge that occurs either as a function of its own experience or by learning from the experiences of others (Argote, 2015). Organizations learn in different ways depending on their learning ability, prior experiences and the knowledge base that they have developed (Barkema and Vermeulen, 1998). Because EMEs have been historically weak in $R \& D$ resources and typically co-evolve with underdeveloped home institutional environments that constrain experimentation-based learning, they may learn and develop technological advantages in ways that differ from their counterparts in developed countries.

First, EMEs learn and develop innovations by imitating and reverse engineering successful products (Malik and Kotabe, 2009). Several EMEs have used this learning method and became global technology leaders over a short period of time. For example, China's Huawei has transformed from a 'copycat' into a global competitive innovator (Luo et al., 2011). According to China's State Intellectual Property Office (SIPO), in 2015, Huawei granted 769 invention patents to Apple, while in return Apple granted 98 to Huawei. Although sometimes constrained by weak internal $R \& D$ resources, EMEs are able to leverage on their abilities to acquire, purchase and license key components and technologies in open markets, and to learn from disassembling products into observable technological components of lower complexity (Malik and Kotabe, 2009), which can lead to the development of architectural innovations (Henderson and Clark, 1990).

Second, EMEs overcome their internal weaknesses in R\&D resources and catch up by indirect learning, i.e., learning through observing, incorporating and sharing others' experiences 
(Banerjee et al., 2015). As opposed to multinational corporations (MNCs) from developed economies, which have been accumulating R\&D resources for decades, EMEs must develop such resources in much shorter periods of time because they are typically situated in underdeveloped institutional environments but are in the same time amid intense global competition. Therefore, EMEs overcome their weak R\&D resources by learning indirectly through their leaders, their industry competitors, and other firms in their networks (e.g., suppliers) who operate in developed countries (Banerjee et al., 2015).

Specifically, OFDI acts as a key vehicle for the organizational learning of EMEs. Liberalization in emerging markets has initially enabled EMEs to benefit from inward FDI in their home markets through demonstration effects, linkages with suppliers, customers and competitors, and employee turnover (e.g., Zhang et al., 2010). For example, Nanjing Automobile Corporation (NAC) was among the first Chinese companies in 1986 to receive FDI from Italy's FIAT and by 2004 it had formed 14 Joint Ventures with FIAT and reached an annual production of 200,000 vehicles (Rui and Yip, 2008). In particular, learning through joint ventures and strategic alliances (e.g., via original equipment manufacturers (OEMs)) has helped EMEs forge network ties with technology leaders (Li et al., 2012; Luo and Tung, 2007) and accumulate international experience and $R \& D$ resources, thus laying the foundation for international learning through OFDI.

The literature on EMEs' OFDI suggests that because these firms have limited conventional ownership advantages (e.g., global brand recognition and proprietary knowledge) that can be exploited when venturing abroad, they didn't follow traditional models in which foreign subsidiaries learn from the parent (Luo et al., 2011). Instead, EMEs' subsidiaries learn from the local markets by imitating known processes to manufacture products, by acquiring the 
technological knowledge of local entities and by exploiting relationships with individuals, competitors and networks (Srinivasan et al., 2007). For example, Chinese BOE Technology Group acquired Hydis, the South Korean manufacturer of TFT-LCD technologies, making BOE the first Chinese MNC to hold core technological assets and capabilities on TFT-LCD panels (Peng, 2003). In a similar vein, the strategic intent perspective suggests that EMEs establish subsidiaries overseas via merger and acquisitions (M\&As) in order to get access to the strategic assets of the acquired companies (Rui and Yip, 2008).

While OFDI in other emerging economies allows EMEs to benefit from global economies of scale and increase market share, it only leads to incremental advances in organizational learning (Rabbiosi et al., 2012) because they are exposed to underdeveloped markets and institutions, local firms with weak R\&D resources and less-demanding customers. By contrast, when EMEs expand to developed markets with industry-specific comparative technological advantages, they can benefit from knowledge spillovers and gain access to valuable R\&D resources and skilled labour. For example, in these markets, EMEs can improve their organizational learning as local customers' sophistication and rapidly changing needs force them to continuously improve and innovate (Rabbiosi et al., 2012). Nevertheless, although the innovative capacity of each country differs (Porter and Stern, 2001), internationalization in multiple countries provides EMEs with exposure to diverse and broad organizational learning opportunities and sources, which increases EMEs' knowledge base and R\&D capabilities in the aggregate.

\subsection{China's innovation and OFDI performance: An overview}


China has witnessed remarkable economic growth in recent years and plays a crucial role in the global innovation battlefield. China's R\&D expenditures in 2012 totalled US $\$ 163$ billion, the $2^{\text {nd }}$ largest in the world, and its ratio of R\&D to GDP was $1.98 \%$ in 2012 , almost matching that of EU-28 as well as closing the gap with the USA and Japan (Eurostat, 2015). The increased R\&D expenditure and rapid economic and institutional transformation has enabled China to overtake the US and to assume the world lead in intellectual property output as of 2012 (WIPO, 2012).

OFDI, in particular, has become a crucial part of China's economic and innovation development plan since the late 1990s (Luo and Tung, 2007). With the 'visible' hand of the Chinese government affecting key decisions such as resource allocation (e.g., low-cost loans, funding, and tax incentives) and geographic location choices (developed vs. emerging economies), Chinese EMEs have become the world's third largest foreign investors, investing an estimated US\$101 billion in 2013 (WIR, 2014). Indeed, internationalized Chinese companies such as Haier, Lenovo, TCL, Galanz, Baosteel, and Sinopec have grown to become global competitors. OFDI has helped Huwaei and ZTE, for example, to increase their international technological competitiveness by tapping into markets and foreign advanced knowledge and technology, and reach the world's second and third positions in patent applications in 2014 (Fan, 2011).

To enable the innovation-enhancing effect of internationalization, many Chinese EMEs locate subsidiaries in countries which offer greater potential for networking, strategic alliances and knowledge spillovers. For example, China-based Galanz, the world's largest microwave manufacturer, established a R\&D centre in Washington (USA) to access R\&D resources and human talent in order to improve its innovative capabilities (Deng, 2007). Going global through 
OFDI strategies has thus enabled latecomer Chinese EMEs to acquire new and complementary $R \& D$ resources and, therefore, to catch up with leading global players.

\section{Hypotheses Development}

\subsection{OFDI and EMEs' innovation performance}

The scant research that has examined the performance outcomes of EMEs' OFDI suggests that internationalization can have both positive and negative effects on EMEs' performance. For instance, EMEs' weak competitive advantages and inexperience in foreign markets can counteract the positive effects of international expansion (Contractor et al., 2007). Nevertheless, we expect that OFDI positively affects EMEs' subsidiaries innovation performance on average by means of international learning.

First, OFDI helps EMEs benefit from knowledge and technology externalities in the host country. EMEs' international networks of subsidiaries allow access and assimilation of globally dispersed pools of ideas and specialized knowledge regarding scientific advances and technological developments (Kafouros et al., 2012). Such spillovers provide information and complementary technological resources, enhancing learning and enabling subsidiaries of EMEs to augment innovation. For example, Chinese subsidiaries are frequently established in hostcountry technology clusters, such as auto maker JAC Anhui Jianghuai, which established a subsidiary in Turin, Italy to benefit from the proximity and knowledge spillovers from the Moncalieri cluster (Nicolas and Thomsen, 2008).

Second, EMEs can augment their organizational learning by collaborating with more advanced firms and institutions in the host country. This in turn enables EMEs' subsidiaries to tap into knowledge that is embedded in firms, people and institutions at specific locations (Porter 
and Stern, 2001), to un-embed certain technologies and knowledge and to re-embed it in their own pool of R\&D resources and technologies (Erkelens et al., 2015). For instance, Huawei’s collaboration with NEC, 3COM, Siemens, and Nortel allowed the company to facilitate its R\&D learning in $3 \mathrm{G}$, routers, and broadband technologies and to increase its innovation performance (Fan, 2011). Networking and collaborative activities in the host country also enables EMEs' subsidiaries to identify and recruit foreign scientific talent who can help to search and assimilate advanced knowledge, enhancing learning (Li et al., 2012).

Third, EMEs' subsidiaries can improve their organizational learning and innovation by integrating knowledge and ideas from their suppliers, customers and distributors in the host country. Suppliers and customers can act as the real creators of innovation because the majority of new products and services are co-developed, or refined, by these users (Von Hippel, 1988). For example, customers can provide ideas about how to improve an existing product's features and design. Furthermore, EMEs can share complementary resources by working with global suppliers and distributors in foreign locations, which enhances their organizational learning and performance (Luo and Tung, 2007). In this case, EMEs' subsidiaries learn and create knowledge during the course of real-time production as they attempt to solve problems related to reverse engineering and product adaptation (Malik and Kotabe, 2009).

However, the proposed innovation-enhancing effects of OFDI are not uniform but depend on the absorptive capacity of EMEs' subsidiaries, i.e., the ability of a firm to recognize the value of new, external information, to assimilate it and to apply it to commercial ends (Cohen and Levinthal, 1990, p.128). Absorptive capacity enables EMEs' subsidiaries to be receptive to external information (Laursen and Salter, 2006), to sense and acquire new knowledge (Song et al., 2011), and to integrate such knowledge into their knowledge repertoires. Although EMEs are 
often constrained by weaker R\&D capabilities, many Chinese internationalized firms have managed to accumulate a sufficient threshold of technological capabilities by benefiting from spillovers of inward FDI in their home markets ( $\mathrm{Li}$ et al, 2012). Moreover, EMEs that venture abroad are typically larger in size, have achieved success in their home markets and therefore are equipped with relatively stronger absorptive capacity. In addition, EMEs can rely on hiring hostcountry local talent to manage their foreign operations (e.g., Lenovo's and Haier's US headquarters are managed by local CEOs) (Luo and Tung, 2007) which compensates for their lack of experiences and capabilities. Hence, we propose:

Hypotheses 1: The OFDI that EMEs' subsidiaries undertake is positively associated with their innovation performance.

\subsection{The moderating role of location choices}

Although OFDI may, on aggregate, enhance the innovation performance of the internationalizing EMEs's subsidiaries, we expect the host country's level of development to moderate the focal relationship. First, because developed countries provide more opportunities to gain access to cluster-specific environments for innovation (Porter and Stern, 2001), sophisticated technologies, and advanced manufacturing know-how (Luo and Tung, 2007), they serve as 'learning laboratories' for internationalized EMEs. This helps EMEs' subsidiaries benefit from technology spillovers, achieve greater learning and enhance innovation.

Second, developed countries offer more opportunities to foster network ties with knowledge-intensive firms, competitors and universities and to recruit better educated and more experienced local 'talent' (Crescenzi et al., 2013). EMEs' subsidiaries can take advantage of such opportunities to offset their R\&D weaknesses and enhance organizational learning (Luo and 
Tung, 2007). In this respect, prior research shows that foreign firms operating in the USA obtain access to high-quality scientists, designers and engineers who assist them in learning advanced technologies and knowledge (Florida, 1997).

Third, the demand conditions in developed economies offer internationalized EMEs both a window of market opportunities providing 'early warning indicators' of global market trends and the pressure to meet high standards (Porter, 1990). EMEs' subsidiaries can improve their organizational learning as the sophistication of foreign customers and rapidly changing consumer needs force them to continuously improve and innovate (Rabbiosi et al., 2012). They can also benefit from the presence of capable suppliers with whom they can create constant and selfreinforcing exchanges of ideas and knowledge (Porter, 1990).

By contrast, the innovation-enhancing effects of OFDI will be weaker when EMEs locate foreign subsidiaries in emerging countries, which typically offer fewer opportunities for sourcing advanced knowledge and technologies because of their overall lower levels of economic and technological development. EMEs in such markets face several emerging country-specific weaknesses, such as underdeveloped markets, less demanding/sophisticated customers, technologically less capable suppliers and less knowledge-intensive universities (Madhok and Keyhani, 2012), which can limit their subsidiaries' learning opportunities. Therefore, EMEs' subsidiaries in emerging countries will not be motivated to develop innovations, but will instead focus their efforts to adapt their existing technologies and products to local market needs (Chittoor et al., 2015). Hence:

Hypotheses 2: The positive effect of OFDI on the innovation performance of EMEs' subsidiaries will be stronger for OFDI in developed economies than for OFDI in emerging economies. 


\section{Data and methods}

\subsection{Empirical Setting and Data}

We constructed a novel panel dataset for the period of 2001-2012 to test our framework and hypotheses. Information regarding Chinese firms' OFDI activities was obtained from the Annual Reports of Publicly Listed Chinese Enterprises, from which we extracted firm-specific information, such as firm age, number of employees, ownership structure, R\&D intensity, the number of overseas subsidiaries, the amount of investment by each subsidiary, and host-country location(s). We further collected information on innovation patents per foreign subsidiary from China's SIPO and linked them to the parent company in China. Using a unique company code, we cross-linked and collated the information extracted from these two sources for each company. We matched the data from the three sources and arrived at a total number of 2,661 Chinese firms. After removing service firms (856) and firms without complete information (10), we were left with 1,795 manufacturing firms. Because this study focuses on the effects of OFDI on innovation performance, we limited the empirical context to high-technology manufacturing industries that have been identified in prior studies of Chinese high-technology industries (e.g., Liu and Buck, 2007). After further removing firms in other (low-tech) industries, we were left with 96 high-tech firms with 717 subsidiary-year observations for the 2001-2012 period ${ }^{1}$.

Table 1 displays the descriptive statistics of Chinese EMEs' OFDI. Section A shows that the OFDI of the sampled Chinese EMEs is concentrated in developed countries. Because these countries provide a larger pool of knowledge and technology, the geographic distribution of Chinese EMEs' OFDI should facilitate organizational learning and enhance innovation

\footnotetext{
${ }^{1}$ Because the number of a Chinese EME's foreign subsidiaries varies each year (e.g., it may have 1 subsidiary in 2001, 2 in 2003 and 0 in 2011), it was impossible to build a balanced panel dataset. We thus counted the numbers of foreign subsidiaries and the years each existed during the sample period, which resulted in a total number of 717 subsidiaryyear observations.
} 
performance. Further, section B shows that Chinese EMEs are clustered in high-tech industries such as telecommunications equipment and electronics. These industries are more dynamic and provide more technological opportunities for EMEs to imitate and reverse engineer successful products and learn through observing, incorporating and sharing others' experiences (Banerjee et al., 2015).

[Insert Table 1 about here]

\subsection{Measures}

\section{Dependent Variable}

We measure innovation performance by the number of forward patent citations a firm has received. Compared with patent-based measures, the number of forward patent citations better captures the quality of innovation (Fleming and Sorenson, 2001). Previous research suggests that the number of forward patent citations that a patent receives is positively associated with its technological importance (Fleming and Sorenson, 2001) and with an invention's value (Wagner and Wakeman, 2016). Because self-citations can create noise (Wagner and Wakeman, 2016), our measure includes only citations by other firms. The SIPO classifies patents into invention patents, design patents and utility patents. Our measure includes invention patents only because they may more accurately reflect the level of a firm's product innovativeness (Fleming and Sorensen, 2001).

\section{Independent Variables}

Our key independent variable is Overall investment in foreign countries, defined as the ratio of total value of OFDI to total investment of each firm. Compared with studies that use the amount of OFDI as an independent variable (e.g., Wang et al., 2012), our operationalization can 
control for the effects of firm size, which may be directly associated with the number of patents. We further constructed two measures - Investment in developed countries and Investment in emerging countries - using the same definition of foreign investments (for a full explanation of this division, see World Bank, 2016a; 2016b). To create these two groups of host countries, we subtracted each host country's real gross domestic product per capita (in PPPs) from the Penn World Table (PWT). The PWT converts national GDP prices into a common currency (US dollars) to make them comparable across countries. From the $8^{\text {th }}$ version of the PWT, we extracted information on country-level gross domestic product per capita (GDPP) for the 20002010 period based on 2005 International Comparisons Program (ICP) prices. We compared the GDPP value of the relative host country with the corresponding value for China. Based on this comparison, we divided host countries into two groups: developed and emerging countries (China belongs to the latter category).

\section{Control Variables}

We first measured firm size by using the logarithmic transformation of each firm's total assets (Eisenberg et al., 1998; Larraza-Kintana et al., 2007). We also included firm age, which was measured by the number of years since the establishment of the parent company. Firm size and age might influence our results because smaller and younger firms tend to produce more new (innovative) products than larger firms (e.g., Stock et al., 2002). Another variable associated with innovation and risk taking is a firm's state ownership. We obtained information on this variable from the Chinese Firms' Equity Change Database (obtained through the China Stock Market \& Accounting Research, CSMAR, database). Following previous studies, we measured state ownership as the ratio of state-owned capital over total capital. The higher the degree of state 
ownership, the more likely the firm will conform to home-country institutional pressures because of its increased dependence on the government for resources (Cui and Jiang, 2012; Guan et al., 2009).

A fourth firm-specific variable associated with innovation is R\&D intensity. The previous research confirms the relationship between a firm's R\&D intensity and its effect on innovation (e.g., Guan et al., 2009; Hitt et al., 1997). We measured $R \& D$ intensity as the firm's ratio of R\&D expenditures to total sales (e.g., Laursen and Salter, 2006). Fifth, we controlled for the influences of TMT size, which is calculated as the number of TMT members. Sixth, we controlled for TMT overseas experience, which is measured as the number of TMT members with overseas experience. Seventh, we controlled for a firm's entry mode, which is constructed as a dummy ( $=1$ if the OFDI takes the form of wholly owned subsidiary and 0 otherwise).

We also control for a number of country-, industry- technology- and time-specific effects. Because its locational attribute might be an important driver of a firm's external knowledge towards innovation, we use country-specific $R \& D$ knowledge, which is defined as $R \& D$ stock/GDP in each host country, to control for this effect. Based on the commonly employed perpetual inventory method (Griliches, 1992; Kafouros et al., 2012), we measured the R\&D (or knowledge) stock created by a foreign country over time by aggregating its current and prior $R \& D$ investments. To account for depreciation and the declining usefulness of $R \& D$, we followed previous studies and used a 15 percent rate of depreciation (Goto \& Suzuki, 1989; Pakes \& Schankerman, 1984). We subtracted data on the ratio of R\&D stock/GDP from the World Development Indicators maintained by the World Bank ${ }^{2}$. Because the Chinese government's 'Go-Global' strategy has prioritized (and incentivized) OFDI activities for selected

\footnotetext{
${ }^{2}$ http://databank.worldbank.org/data/reports.aspx?source=world-development-indicators\#
} 
industries (Wang et al., 2012), we included industry dummies to account for industry heterogeneity. Furthermore, patents granted to the firms in our sample were assigned to different patent subclasses. As this might be an important -though unobserved-driver of patenting associated with the underlying characteristics of the technology itself (beyond mere industry categorization), we included technology class dummies in the analyses. Finally, we generated year dummies to control for the time-specific effect. Table 2 provides a summary of the variables and data sources.

[Insert Table 2 about here]

\subsection{Estimation method}

Because the dependent variable, innovation performance, is measured by the number of forward patent citations an EME's foreign subsidiary received, we use a count model. Two types of count models, namely, Poisson regression and Negative Binomial regression, can be adopted. The Poisson regression assumes that the mean and variance are the same, which is not suitable for our dataset because the summary statistics show that they are different. By contrast, although the Negative Binomial regression model can be viewed as an extension of the Poisson regression, it addresses the over-dispersion issue better and has parameterizations that differ from the Poisson model. We took the logarithm for the dependent variable and all key independent variables to facilitate the interpretation of our results. Finally, we lagged all the explanatory variables by one year, except for the dummies, to account for the fact that some predicted effects take time to materialize. The use of a lag structure allowed us to control for possible simultaneity bias (Aitken and Harrison, 1999). We estimated the Negative Binomial regression model using the Maximum Likelihood method. 


\section{Results}

Table 3 reports the descriptive statistics and pairwise correlations of the variables used. All correlations are fairly low, except for the correlation between overall foreign investment and investment in emerging countries, which is expected (but the two variables do not appear in the same regression). We calculated variance inflation factors (VIFs) and found that all VIFs were substantially below the acceptable level of 10 (Neter et al., 1985). The results thus indicate that multicollinearity is not a serious concern. To further eliminate the problem of multicollinearity and enhance the interpretation of interactions, we mean-centred the variables before generating those interaction terms (Aiken and West, 1991).

[Insert Table 3 about here]

Table 4 reports the results. Model 1 serves as the baseline model and includes control variables only. The main predictor variable, Overall investment in foreign countries, is added to Model 2. The coefficient of this variable is positive and significant in this model, thus providing support for Hypothesis 1, which predicts that the OFDI is positively associated with the innovation performance of Chinese EMEs' subsidiaries. The coefficient of this variable indicates that a 1 per cent increase in the ratio of foreign investment in the firm's total investment will lead to a 0.302 per cent increase in the number of patent citations. In Model 3, the coefficient of investment in developed is highly significant, whilst the coefficient of investment in emerging countries is only marginally significant. Nevertheless, to test Hypothesis 2, we conducted the Wald test to compare the value of the two coefficients. The result rejected the null hypothesis that two coefficients are the same at 5\% level of significance. Hence, Hypothesis 2 (that the 
positive effect of OFDI on innovation performance would be stronger for OFDI in developed countries than for OFDI in emerging countries) is supported.

[Insert Table 4 about here]

\section{Robustness Checks}

One concern that may arise is that the foreign investment variable may be endogenous, as innovation performance may also influence OFDI. However, this possibility is likely to be minimal because most Chinese firms have only invested overseas in recent years, which leads OFDI to be less likely to depend on certain firm-specific characteristics (Wang et al., 2012). Nevertheless, we took measures to overcome this concern by incorporating a wide set of individual-level covariates as controls for important differences in firm characteristics. Our adoption of a lag structure for all independent variables should also help to control for possible endogeneity (Aitken and Harrison, 1999).

Furthermore, we employed the Hausman test (Hausman, 1978) to examine the endogeneity of the variable for overall investment in foreign countries. To do so, we had to identify a valid instrumental variable (IV). Following standard practice (Gujarati, 2009), we carefully selected an IV, i.e., whether a firm's headquarters were located in the capital of the home country. A valid instrument should be correlated with the suspected endogenous variable (foreign investment) while simultaneously being orthogonal to the error term. When a Chinese firm is headquartered in Beijing, it is easier to raise capital for foreign investments. Moreover, because Beijing is headquarters to many large companies which engage in OFDI, EMEs are likely to imitate the practice of these firms and internationalize to reduce uncertainty and enhance their legitimacy (Wang et al., 2012). We thus posit that whether a firm's headquarters 
are located in the capital is a good instrument for the foreign investment variable. To verify this as a valid IV, we conducted the exclusion restriction test. We first obtained the residual from the first-stage estimations and then regressed the residual on the IV. The estimated effect on the IV is statistically insignificant $(\mathrm{p}=0.0 .451)$, indicating that the instrumental variable is indeed uncorrelated with the error term. Second, we conducted the Hausman test to examine the endogeneity of the focal variable. The results show that the Chi-square value is 0.20 with a pvalue of 0.657 , which cannot reject the null hypothesis that the differences between the original model and the 2SLS estimated coefficients are not systematically different. This result suggests that the foreign investment variable is indeed exogenous and that the results of our estimation are not biased.

Second, we extend our sample of high-tech firms to include all manufacturing firms $(n=1,795)$ to determine whether the key results continue to hold. We first estimated our benchmark negative binomial regression and show the results in Table 5. The key results related to our hypotheses are qualitatively consistent with those in Table 4 . We then estimated the random effect models, which helps to account for the effects of unobserved heterogeneity that arises because 'each firm contributes multiple observations that are not independent from each other' (Jensen and Zajac, 2004). We did not use the fixed effect model because the negative binomial model is a non-linear function and the likelihood estimator for fixed effects will generate biased and inconsistent results. The results are shown in Table 6. As can be seen, the level of significance for the coefficients of overall investment in foreign countries and investment in developed countries was reduced to 5\%, whilst the coefficient for investment in emerging countries becomes statistically insignificant. These results are still qualitatively unchanged and corroborate our two hypotheses. 
[Insert Tables 5 and 6 about here]

\section{Discussion and conclusion}

\subsection{Implications for theory and practice}

Although innovation scholars conceptualize that organizational learning lies at the heart of our understanding of an organization's capacity to innovate (Alegre and Chiva, 2008; Hurley and Hult, 1998), and International Business (IB) research conceives of a firm's internationalization as a process of organizational learning (Johanson and Vahlne, 1977), little effort has been undertaken to establish a conceptual link between internationalization, organizational learning and innovation (Hotho et al., 2015). Our first contribution therefore lies in creating a framework that integrates internationalization and innovation - two largely isolated bodies in the previous literature- by adding organizational learning to the focal nexus. Our theoretical integration allows us not only to add another layer of understanding to the effect of OFDI on EMEs' innovation performance but also to explain the theoretical mechanisms that drive this relationship; therefore, we add to a more nuanced understanding of the innovation performance implications of internationalization.

The results of the study support our conceptual framework by showing that Chinese EMEs' subsidiaries can improve their innovation performance by successfully accessing knowledge and technologies and by learning from host market environments (Phene and Almeida, 2008). This finding extends beyond the research that focuses exclusively on the explanations of knowledge-seeking as a motivation for EMEs' OFDI in developed markets (e.g., Luo and Tung, 2007) and instead allows us to advance the literature by concentrating on the innovation outcomes of OFDI. We also find that this innovation strategy works better when 
EMEs target developed countries endowed with better innovation systems, more-demanding customers, and with firms competing at the top of the value chain. These findings extend the literature by demonstrating that the innovation-enhancing effect of EMEs' internationalization depends not only on OFDI per se but also on the geographic location choices of EMEs' subsidiaries that influence subsequent knowledge acquisition (Bathelt and Henn, 2014; Fan, 2011).

Our study also contributes to organizational learning theory. The findings and assumptions regarding organizational learning and knowledge assimilation are largely based on studies of MNCs from developed countries (e.g., Phene and Almeida, 2008). As a result, little is known about whether and how EMEs' subsidiaries develop innovation by means of their distinct ways of organizational learning. Our findings enrich organizational learning theory by theorizing how latecomer Chinese EMEs overcome their weak internal capabilities and time compression diseconomies by accelerate learning in foreign markets in a manner that is suited to their firmspecific characteristics. This finding suggests that scholars should exercise caution when applying existing organizational learning frameworks to EMEs. Additionally, by demonstrating that the innovation-enhancing effect of internationalization is higher for OFDI in developed than in emerging countries, our finding also deviates from the Uppsala model of international learning (Johanson and Vahlne 1977) that suggests that the greater the psychological distance between a firm's home and foreign environment, the more a firm's learning ability is eroded (Zeng et al., 2013). We show that variations in location choices can explain why internationalization of two EMEs with similar characteristics may yield differential innovation outcomes.

This study also offers some practical implications for managers of EMEs. Our results suggest that EMEs' managers enhance their subsidiaries' innovation performance through 
international learning by engaging in OFDI. This proves to be an effective way of learning because it allows EMEs to overcome path-dependency and avoid underdeveloped home institutional environments that often constrain experimentation-based learning. Furthermore, our analysis suggests that when OFDI is motivated by international learning, location choices are critical for achieving this objective. In this respect, our results suggest that EMEs should locate more OFDI projects in developed economies endowed with world-class universities, research centres, demanding customers and highly innovative firms. Although this might pose intense competitive pressures, similar to which they have never been exposed to, it can also provide opportunities for latecomer EMEs to accelerate organization learning and catch up with global technology leaders in a relatively short period of time. This recommendation challenges the conventional prescription that emphasizes the importance of developing internal competencies, and it suggests that capability-constrained EMEs should integrate organizational learningoriented OFDI into their innovation strategies.

\subsection{Limitations and directions for future research}

As with similar single-country studies, one limitation of this study concerns the generalizability of the results. Although we acknowledge that China is currently the $3^{\text {rd }}$ largest 'power' in OFDI, other emerging economies such as Russia also exhibit impressive OFDI expansion. Future research should therefore aim to examine whether OFDI by EMEs from other emerging economies fosters organization learning and in turn enhances their subsidiaries' innovation performance. Additionally, because our sample does not incorporate non-listed companies, it is also difficult to generalize the results of our study to all Chinese businesses investing abroad. 
Second, although we have divided our sample of Chinese OFDI into developed and emerging countries, data constraints do not allow us to capture the effect of specific types of knowledge in individual foreign countries. Data constraints also do not allow us to examine the different methods that Chinese EMEs use to access and acquire knowledge from OFDI (e.g., through M\&As, joint venture or wholly owned subsidiary). Third, data constraints regarding our unit of analysis do not allow us to measure the effect of Chinese OFDI on the innovation performance of the entire company. Future research should examine whether an EME's network of foreign subsidiaries diffuses advanced knowledge, $R \& D$ and innovation capabilities to the headquarters and across their brother units around the world, and thus enhancing the innovation performance of the entire EME.

\section{Acknowledgement}

This work was supported by the National Natural Science Foundation of China (grant number: 71563058), the British Academy (grant number: 510074) and the Joint Research Funding Scheme between Ningbo City Government and Chinese Academy of Social Sciences. 


\section{References}

Aitken, B. J., \& Harrison, A. E. 1999. Do domestic firms benefit from direct foreign investment? Evidence from Venezuela. American Economic Review, 89(3): 605-618.

Aiken, L.S., \& West, S.G. 1991. Multiple Regression: Testing and Interpreting Interactions. Sage: Newbury Park, CA.

Argote, L. 2015. An opportunity for mutual learning between organizational learning and global strategy researchers: transactive memory systems. Global Strategy Journal, 5(2): 198-203.

Argote, L., \& Ingram, P. 2000. Knowledge Transfer: A Basis for Competitive Advantage in Firms. Organizational Behavior and Human Decision Processes, 82(1): 150-169.

Banerjee, S., Prahbu, J.C., \& Chandy, R.K. 2015. Indirect learning: How emerging-market firms grow in developed markets. Journal of Marketing, 79(1): 10-28.

Barkema, H.G., \& Vermuelen, F. 1998. International Expansion Through Start-Up or Acquisition: A Learning Perspective. Academy of Management Journal, 41(1): 7-26.

Cantwell, J.A. 1989. Technological Innovation and Multinational Corporations. Basil Blackwell: Oxford.

Chittoor, R., Aulakh, P.S., \& Ray, S. 2015. Accumulative and assimilative learning, institutional infrastructure, and innovation orientation of developing economy firms. Global Strategy Journal, 5(2): 133-153.

Cohen, W. M., \& Levinthal, D. A. 1990. Absorptive capacity: A new perspective on learning and innovation. Administrative Science Quarterly, 35(1): 128-152.

Contractor, F.J., Kumar, V., \& Kundu, S.K. 2007. Nature of the relationship between international expansion and performance: The case of emerging market firms. Journal of World Business, 42(4): 401-417. 
Crescenzi, R., Pietrobelli, C., \& Rabellotti, R. 2013. Innovation drivers, value chains and the geography of multinational corporations in Europe. Journal of Economic Geography, 14(6):1053-1086.

Cui, L., \& Jiang, F. 2012. State ownership effect on firms’ FDI ownership decisions under institutional pressure: a study of Chinese outward-investing firms. Journal of International Business Studies, 43(3): 264-284.

Deng, P. 2007. Investing for strategic resources and its rationale: The case of outward FDI from Chinese companies. Business Horizons, 50(1): 71-81.

Eisenberg, T., Sundgren, S., \& Wells, M.T. 1998. Larger board size and decreasing firm value in small firms. Journal of Financial Economics, 48(1): 35-54.

Erkelens, R., van den Hooff, B., Huysman, M., \& Vlaar, P. 2015. Learning from locally embedded knowledge: facilitating organizational learning in geographically dispersed settings. Global Strategy Journal, 5(2): 177-197.

Eurostat. 2015. R\&D Expenditure. [Online]. (downloaded on 27 August 2015 from http://ec.europa.eu/eurostat/statistics-explained/index.php/R_\%26_D_expenditure).

Fan, P. 2011. Innovation, globalization, and catch-up of latecomers: cases of Chinese telecom firms. Environment and Planning A, 43(4): 830-849.

Feenstra, R.C., Inklaar, R., \& Timmer, M.P. 2013. The Next Generation of the Penn World Table. [Online]. (downloaded on 16 November 2011 from:

http://www.rug.nl/research/ggdc/data/pwt/v80/the_next_generation_of_the_penn_world table.pdf).

Fleming, L., \& Sorenson, O. 2001. Technology as a complex adaptive system: Evidence from patent data. Research Policy, 30(7): 1019-1039. 
Florida, R. 1997. The globalization of R\&D: Results of a survey of foreign-affiliated R\&D laboratories in the USA. Research Policy, 26(1): 85-103.

Guan, J.C., Yam, R.C.M., Tang, E.P.Y., \& Lau, A.K.W. 2009. Innovation strategy and performance during economic transition: Evidences in Beijing, China. Research Policy, 38(5): 802-812.

Gujarati, D.N. 2009. Basic econometrics, (5th ed.). McGraw-Hill: New York.

Guillen, M.F., \& Garcia-Canal, E. 2009. The American model of the multinational firm and the "new" multinationals from emerging economies. Academy of Management Perspectives, 23(2): $23-35$.

Hausman, J.A. 1978. Specification tests in econometrics. Econometrica, 46(6): 1251-1271.

Hoskisson, R. E., Wright, M., Filatotchev, I., \& Peng, M.W. 2013. Emerging multinationals from mid-range economies: The influence of institutions and factor markets. Journal of Management Studies, 50(7): 1295-1321.

Hotho, J.J., Lyles, M.A., \& Easterby-Smith, M. 2015. The mutual impact of global strategy and organizational learning. Global Strategy Journal, 5(2): 85-112.

Jensen, M., \& Zajac, E.J. 2004. Corporate elites and corporate strategy: how demographic preferences and structural position shape the scope of the firm. Strategic Management Journal, 25(6): 507-524.

Johanson, J., \& Vahlne, J.E. 1977. The internationalization process of the firm: A model of knowledge development and increasing foreign market commitments. Journal of International Business Studies, 8(1): 25-34. 
Kafouros, M.I., Buckley, P.J., Clegg, J. 2012. The effects of global knowledge reservoirs on the productivity of multinational enterprises: The role of international depth and breadth. Research Policy, 41(5): 848-861.

Laursen, K., \& Salter, A., 2006. Open for innovation: the role of openness in explaining innovation performance among UK manufacturing firms. Strategic Management Journal 27(2): 131-150.

Li, J., Li, Y., \& Shapiro, D. 2012. Knowledge seeking and outward FDI of emerging market firms: the moderating effect of inward FDI. Global Strategy Journal, 2(4): 277-295.

Li, J.J., Poppo, L., \& Zhou, K.Z. 2008. Do managerial ties in China always produce value? Competition, uncertainty, and domestic vs foreign firms. Strategic Management Journal, 29(4): 383-400.

Liu, F.C., Simon, D.S., Su, Y.T., \& Cao, C. 2011. China's innovation policies: Evolution, institutional structure, and trajectory. Research Policy, 40(7): 917-931.

Liu, X., \& Buck, T. 2007. Innovation performance and channels for international technology spillovers: Evidence from Chinese high-tech industries. Research Policy, 36(3): 355-366.

Luo, Y., Sun, J., \& Wang, S.L. 2011. Emerging Economy Copycats: Capability, Environment, and Strategy. Academy of Management Perspectives, 25(2): 37-56.

Luo, Y., \& Tung, R.L. 2007. International expansion of emerging market enterprises: A springboard perspective. Journal of International Business Studies, 38(4): 481-498.

Madhok, A., \& Keyhani M. 2012. Acquisitions as entrepreneurship: asymmetries, opportunities, and the internationalization of multinationals from emerging economies. Global Strategy Journal, 2(1): 26-40. 
Malik, O.R., \& Kotabe, M. 2009. Dynamic Capabilities, Government Policies, and Performance in Firms from Emerging Economies: Evidence from India and Pakistan. Journal of Management Studies, 46(3): 421-450.

Neter, J., Wasserman, W., \& Kutner, M. 1985. Applied Linear Statistical Models. Richard D. Irwin: Homewood, Illinois.

Nicholas, F., \& Thomsen, S. 2008. The Rise of Chinese Firms in Europe: Motives, Strategies and Implications. Draft Paper for presentation at the Asia Pacific Economic Association Conference, to be held in Beijing, December $13-14,2008$ (downloaded on $20^{\text {th }}$ of March 2017 from https://www.researchgate.net/publication/240642216_The_Rise_of_Chinese_Firms_in_E urope_Motives_Strategies_and_Implications).

Peng, M.W. 2003. Institutional transitions and strategic choices. Academy of Management Review, 28(2): 275- 296.

Phene, A., \& Almeida, P. 2008. Innovation in multinational subsidiaries: The role of knowledge assimilation and subsidiary capabilities. Journal of International Business Studies, 39(5): 901-919.

Porter, M.E. 1990. The competitive advantage of nations. The Free Press: USA.

Porter, M.E., \& Stern, S. 2001. Innovation: Location Matters. MIT Sloan Management Review, 42(4): $28-36$.

Rabbiosi, L., Elia, S., \& Bertoni, F. 2012. Acquisitions by EMNCs in Developed Markets: an Organisational Learning Perspective. Management International Review, 52(2): 193-212. 
Srinivasan, R., Haunschild, P., \& Grewal, R. 2007. Vicarious Learning in New Product Introductions in Early Years of a Converging Market. Management Science, 53(1): 1628.

Song, J., Asakawa, K., \& Chu. Y. 2011. What determines knowledge sourcing from host locations of overseas R\&D operations?: A study of global R\&D activities of Japanese multinationals. Research Policy, 40(3): 380 - 390.

Stock, G.N., Greis, N.P., \& Fischer, W.A. 2002. Firm size and dynamic technological innovation. Technovation, 22(9): 537-549.

Tung, R.L. 2007. The human resource challenge to outward foreign direct investment aspirations from emerging economies: The case of China. The International Journal of Human Resource Management, 18(5): 868-889.

Von Hippel, E. 1988. The Sources of Innovation. New York: Oxford University Press.

Wagner, S., \& Wakeman, S. 2016. What do patent-based measures tell us about product commercialization? Evidence from the pharmaceutical industry. Research Policy, 45(5): 1091-1102.

Wang, C., Hong, J., Kafouros, M., \& Wright, M. 2012. Exploring the role of government involvement in outward FDI from emerging economies. Journal of International Business Studies, 43(7): 655-676.

WIPO (World Intellectual Property Organization). 2012. World Intellectual Property Indicators. (Downloaded on 4 February 2013 from http://www.wipo.int/edocs/pubdocs/en/intproperty/941/wipo_pub_941_2012.pdf).

World Bank. 2016a. Country and Lending Groups. [online]. [Accessed $5^{\text {th }}$ of June 2016]. Available from: http://data.worldbank.org/about/country-and-lending-groups. 
World Bank. 2016b. How does the World Bank classify countries? [online]. [Accessed 5th of June 2016]. Available from:

https://datahelpdesk.worldbank.org/knowledgebase/articles/378834-how-does-the-worldbank-classify-countries.

World Investment Report (WIR) 2014. Investing in the SDGs: An Action Plan. (Downloaded on 12 November 2014 from: http://unctad.org/en/PublicationsLibrary/wir2014_en.pdf).

Wu, J., Wang, C., Hong, J., Piperopoulos, P., \& Zhuo, S. 2016. Internationalization and innovation performance of emerging market enterprises: The role of host-country institutional development. Journal of World Business, 51(2): 251-263.

Zeng, Y., Shenkar, O., Lee, S.H., \& Song, S. 2013. Cultural differences, MNE learning abilities, and the effect of experience on subsidiary mortality in a dissimilar culture: Evidence from Korean MNEs. Journal of International Business Studies, 44(1): 42-65. 


\section{Table 1}

Locations of OFDI and industry distribution of sample firms

Section A: Locations of OFDI

Developed countries

Emerging countries

Total

Section B: Industry distribution of OFDI

Specialized Chemical Products

Consumer Chemical Products

Consumer Electronics

Other Electronic Appliance

Electrical Machinery and Equipment

Electrical Machinery

Electrical Instrument

Biological Medicines

Communications \& Related Equipment

Communications Equipment

Computer related Equipment

Total
No. of Chinese EMEs

$76(79 \%)$

$20(21 \%)$

96

No. of Chinese MNEs

No. of subsidiary-year observations

$$
607(85 \%)
$$

$110(15 \%)$

717

No. of subsidiary-year observations

$13 \quad 70$

3

34

10

83

19

95

2

16

7

77

6

43

5

47

1

20

26

201

4

31

96 


\section{Table 2}

Variables and data sources

\begin{tabular}{|c|c|c|}
\hline Variables & Description & Sources \\
\hline $\begin{array}{l}\text { Innovation } \\
\text { performance }\end{array}$ & $\begin{array}{l}\text { The number of forward patent citations a subsidiary has } \\
\text { received }\end{array}$ & SIPO, China \\
\hline $\begin{array}{l}\text { Overall investment } \\
\text { in foreign countries }\end{array}$ & The ratio of total value of OFDI to total investment & $\begin{array}{l}\text { Collected from firm's annual financial } \\
\text { reports }\end{array}$ \\
\hline $\begin{array}{l}\text { Investment in } \\
\text { developed countries }\end{array}$ & $\begin{array}{l}\text { The ratio of total value of OFDI to total investment for each } \\
\text { EME that has invested in developed foreign countries }\end{array}$ & $\begin{array}{l}\text { Collected from firm's annual financial } \\
\text { reports }\end{array}$ \\
\hline $\begin{array}{l}\text { Investment in } \\
\text { emerging countries }\end{array}$ & $\begin{array}{l}\text { The ratio of total value of OFDI to total investment for each } \\
\text { EME that has invested in emerging foreign countries }\end{array}$ & $\begin{array}{l}\text { Collected from firm's annual financial } \\
\text { reports }\end{array}$ \\
\hline Firm size & Log (The number of employees) & CSMAR \\
\hline Firm age & The number of years since the establishment of the parent & CSMAR \\
\hline State ownership & The ratio of state-owned capital over total capital & CSMAR \\
\hline R\&D intensity & The ratio of a firm's R\&D expenditure to total sales & CSMAR \\
\hline TMT's size & The number of TMT members & $\begin{array}{l}\text { Calculated from TMT CV provided } \\
\text { CSMAR Corporate Governance } \\
\text { database }\end{array}$ \\
\hline $\begin{array}{l}\text { TMT's overseas } \\
\text { experiences }\end{array}$ & $\begin{array}{l}\text { The number of TMT members that have overseas } \\
\text { experience }\end{array}$ & $\begin{array}{l}\text { Calculated from TMT CV provided } \\
\text { CSMAR Corporate Governance } \\
\text { database }\end{array}$ \\
\hline Entry mode & $\begin{array}{l}\text { Dummy=1 if OFDI takes the form of wholly owned } \\
\text { subsidiary }\end{array}$ & $\begin{array}{l}\text { Calculated from OFDI database } \\
\text { compiled by authors }\end{array}$ \\
\hline $\begin{array}{l}\text { Country-specific } \\
\text { R\&D knowledge }\end{array}$ & The ratio of R\&D stock/GDP of each foreign country & $\begin{array}{l}\text { World Development Indicators of the } \\
\text { World Bank }\end{array}$ \\
\hline
\end{tabular}




\section{Table 3}

Descriptive Statistics and Correlations

\begin{tabular}{|c|c|c|c|c|c|c|c|c|c|c|c|c|c|c|c|}
\hline & Variables & Mean & S.D. & (1) & (2) & (3) & (4) & (5) & (6) & (7) & (8) & (9) & (10) & (11) & $(12)$ \\
\hline (1) & Innovation performance & 54 & 381 & 1.000 & & & & & & & & & & & \\
\hline (2) & Overall investment in foreign countries & 0.21 & 0.72 & 0.215 & 1.000 & & & & & & & & & & \\
\hline (3) & Investment in developed countries & 0.18 & 0.12 & 0.113 & 0.987 & 1.000 & & & & & & & & & \\
\hline (4) & Investment in emerging countries & 0.06 & 0.38 & 0.131 & 0.079 & -0.065 & 1.000 & & & & & & & & \\
\hline (5) & Firm size & 7.494 & 1.413 & 0.277 & 0.275 & 0.255 & 0.121 & 1.000 & & & & & & & \\
\hline (6) & Firm age & 10.194 & 4.474 & 0.066 & 0.154 & 0.158 & 0.003 & 0.197 & 1.000 & & & & & & \\
\hline (7) & State ownership & 0.112 & 0.194 & 0.089 & 0.051 & 0.036 & 0.052 & 0.083 & 0.113 & 1.000 & & & & & \\
\hline (8) & $R \& D$ intensity & 0.362 & 2.919 & 0.324 & 0.171 & 0.158 & 0.072 & 0.208 & 0.099 & 0.023 & 1.000 & & & & \\
\hline (9) & TMT's size & 18.367 & 4.662 & 0.306 & 0.243 & 0.227 & 0.094 & 0.423 & 0.045 & 0.144 & 0.244 & 1.000 & & & \\
\hline (10) & TMT's overseas experience & 0.021 & 0.145 & -0.017 & -0.021 & -0.020 & -0.014 & 0.059 & 0.090 & 0.217 & -0.019 & -0.056 & 1.000 & & \\
\hline (11) & Entry mode & 0.310 & 0.463 & 0.084 & 0.503 & 0.509 & 0.076 & 0.076 & 0.171 & -0.021 & 0.054 & 0.100 & -0.035 & 1.000 & \\
\hline (12) & Country-specific R\&D knowledge & 1.189 & 0.847 & 0.108 & 0.085 & 0.108 & -0.069 & -0.001 & 0.276 & -0.106 & -0.049 & -0.106 & -0.026 & 0.286 & 1.000 \\
\hline
\end{tabular}

$\mathrm{n}=717$. Correlations with an absolute value greater than 0.03 are significant at $\mathrm{p}<.05$. 
Table 4

Negative binomial regression analyses of OFDI on innovation performance

\begin{tabular}{|c|c|c|c|}
\hline Variables & $(1)$ & (2) & (3) \\
\hline \multirow[t]{2}{*}{ Firm size } & $0.367 * * *$ & 0.088 & 0.091 \\
\hline & $(4.979)$ & $(1.170)$ & $(1.207)$ \\
\hline \multirow[t]{2}{*}{ Firm age } & $0.314 * * *$ & $0.359 * * *$ & $0.362^{* * *}$ \\
\hline & $(9.172)$ & $(11.002)$ & $(11.035)$ \\
\hline \multirow[t]{2}{*}{ State ownership } & 0.599 & $0.845+$ & $0.826+$ \\
\hline & $(1.123)$ & (1.819) & $(1.782)$ \\
\hline \multirow[t]{2}{*}{ R\&D intensity } & $0.154^{*}$ & 0.006 & 0.007 \\
\hline & $(2.473)$ & $(0.092)$ & $(0.116)$ \\
\hline \multirow[t]{2}{*}{ TMT size } & $0.088 * * *$ & $0.073 * * *$ & $0.072^{* * *}$ \\
\hline & $(4.147)$ & $(3.778)$ & (3.711) \\
\hline \multirow{2}{*}{ TMT's oversea experience } & -0.357 & -0.610 & -0.604 \\
\hline & $(-0.474)$ & $(-0.873)$ & $(-0.866)$ \\
\hline \multirow[t]{2}{*}{ Entry mode } & -0.231 & $-1.367^{* * *}$ & $-1.415^{* * *}$ \\
\hline & $(-1.005)$ & $(-5.050)$ & $(-5.150)$ \\
\hline \multirow[t]{2}{*}{ Country-specific R\&D knowledge } & 0.002 & $0.003+$ & 0.003 \\
\hline & $(0.812)$ & (1.651) & (1.596) \\
\hline \multirow[t]{2}{*}{ Overall investment in foreign countries } & & $0.302 * * *$ & \\
\hline & & (7.469) & \\
\hline \multirow[t]{2}{*}{ Investment in emerging countries } & & & $0.284+$ \\
\hline & & & $(1.945)$ \\
\hline \multirow[t]{2}{*}{ Investment in developed countries } & & & $3.427^{* * *}$ \\
\hline & & & $(7.486)$ \\
\hline Year dummy variables & YES & YES & YES \\
\hline Industry dummy variables & YES & YES & YES \\
\hline Technology class dummy variables & YES & YES & YES \\
\hline Constant & -35.089 & -28.091 & -26.963 \\
\hline
\end{tabular}




\begin{tabular}{lccc}
\hline & $(-0.070)$ & $(-0.056)$ & $(-0.098)$ \\
Log-likelihood & -1488.91 & -1459.44 & -1459.10 \\
LR $\chi^{2}$ & 466.23 & 525.16 & 525.85 \\
Prob. $>\chi^{2}$ & 0.00 & 0.00 & 0.00 \\
\hline
\end{tabular}

$\mathrm{N}=717$; t-statistics are reported in parentheses. + if $\mathrm{p}<.10,{ }^{*}$ if $\mathrm{p}<.05 ;{ }^{* *}$ if $\mathrm{p}<.01 ;{ }^{* * *}$ if $\mathrm{p}<.001$ (two-tailed test) 
Table 5

Negative binomial regression analysis (for all manufacturing firms)

\begin{tabular}{|c|c|c|c|}
\hline Variables & (1) & (2) & (3) \\
\hline \multirow[t]{2}{*}{ Firm size } & $0.489 * * *$ & $0.459 * * *$ & $0.460^{* * *}$ \\
\hline & $(24.376)$ & (22.258) & $(22.305)$ \\
\hline \multirow[t]{2}{*}{ Firm age } & $0.121 * * *$ & $0.114^{* * *}$ & $0.115^{* * *}$ \\
\hline & $(13.506)$ & $(13.098)$ & (13.092) \\
\hline \multirow[t]{2}{*}{ State ownership } & $0.820 * * *$ & $0.725^{* * *}$ & $0.735^{* * *}$ \\
\hline & $(5.286)$ & $(4.695)$ & $(4.759)$ \\
\hline \multirow[t]{2}{*}{$R \& D$ intensity } & $0.211 * * *$ & $0.200 * * *$ & $0.200^{* * *}$ \\
\hline & $(4.902)$ & (4.575) & (4.538) \\
\hline \multirow[t]{2}{*}{ TMT size } & $0.090 * * *$ & $0.081 * * *$ & $0.082^{* * *}$ \\
\hline & $(11.495)$ & $(10.194)$ & $(10.269)$ \\
\hline \multirow[t]{2}{*}{ TMT's oversea experience } & $-0.569 * *$ & $-0.654^{* *}$ & $-0.657 * *$ \\
\hline & $(-2.654)$ & $(-3.059)$ & $(-3.068)$ \\
\hline \multirow[t]{2}{*}{ Entry mode } & 0.007 & $-0.267 * *$ & $-0.267 * *$ \\
\hline & $(0.084)$ & $(-2.951)$ & $(-2.914)$ \\
\hline \multirow[t]{2}{*}{ Country-specific knowledge } & -0.000 & 0.000 & 0.000 \\
\hline & $(-0.110)$ & $(0.526)$ & $(0.489)$ \\
\hline \multirow[t]{2}{*}{ Overall investment in foreign countries } & & $0.083^{* * *}$ & \\
\hline & & (7.010) & \\
\hline \multirow[t]{2}{*}{ Investment in emerging countries } & & & $0.076+$ \\
\hline & & & $(1.675)$ \\
\hline \multirow[t]{2}{*}{ Investment in developed countries } & & & $0.915^{* * *}$ \\
\hline & & & $(6.777)$ \\
\hline Year dummy variables & YES & YES & YES \\
\hline Industry dummy variables & YES & YES & YES \\
\hline Technology class dummy variables & YES & YES & YES \\
\hline \multirow[t]{2}{*}{ Constant } & $-6.083 * * *$ & $-5.801 * * *$ & $-5.824 * * *$ \\
\hline & $(-19.686)$ & $(-18.616)$ & $(-18.709)$ \\
\hline
\end{tabular}




\begin{tabular}{lccc}
\hline Log-likelihood & -10631.87 & -10605.20 & -10607.08 \\
AIC & 21305.75 & 21254.40 & 21260.17 \\
LR $\chi^{2}$ & 1492.33 & 1545.67 & 1541.91 \\
Prob. $>\chi^{2}$ & 0.00 & 0.00 & 0.00
\end{tabular}

(1) $\mathrm{N}=1795 ;$; (2) t-statistics are reported in parentheses. + if $\mathrm{p}<.10, *$ if $\mathrm{p}<.05 ; * *$ if $\mathrm{p}<.01$; *** if $\mathrm{p}<.001$ (two-tailed test); (3) Results related to control variables are not shown to save space but are available from authors. 
Table 6

Random-effects negative binomial analysis (for all manufacturing firms)

\begin{tabular}{|c|c|c|c|}
\hline Variables & (1) & $(2)$ & (3) \\
\hline \multirow[t]{2}{*}{ Firm size } & $0.188^{* * *}$ & $0.181^{* * *}$ & $0.181 * * *$ \\
\hline & $(7.738)$ & $(7.382)$ & $(7.402)$ \\
\hline \multirow[t]{2}{*}{ Firm age } & 0.008 & 0.009 & 0.008 \\
\hline & $(0.720)$ & $(0.773)$ & $(0.758)$ \\
\hline \multirow[t]{2}{*}{ State ownership } & -0.073 & -0.070 & -0.070 \\
\hline & $(-0.773)$ & $(-0.751)$ & $(-0.751)$ \\
\hline \multirow[t]{2}{*}{ R\&D intensity } & -0.009 & -0.010 & -0.009 \\
\hline & $(-1.408)$ & $(-1.508)$ & $(-1.464)$ \\
\hline \multirow[t]{2}{*}{ TMT size } & $0.023 * * *$ & $0.023 * * *$ & $0.023^{* * *}$ \\
\hline & $(4.368)$ & $(4.224)$ & $(4.263)$ \\
\hline \multirow[t]{2}{*}{ TMT's oversea experience } & 0.052 & 0.048 & 0.050 \\
\hline & $(0.372)$ & $(0.342)$ & $(0.355)$ \\
\hline \multirow[t]{2}{*}{ Entry mode } & $0.085+$ & 0.045 & 0.045 \\
\hline & $(1.868)$ & $(0.935)$ & $(0.933)$ \\
\hline \multirow[t]{2}{*}{ Country-specific knowledge } & 0.000 & 0.000 & 0.000 \\
\hline & $(0.243)$ & $(0.389)$ & $(0.472)$ \\
\hline \multirow[t]{2}{*}{ Overall investment in foreign countries } & & $0.017^{*}$ & \\
\hline & & $(2.208)$ & \\
\hline \multirow[t]{2}{*}{ Investment in emerging countries } & & & 0.024 \\
\hline & & & $(1.213)$ \\
\hline \multirow[t]{2}{*}{ Investment in developed countries } & & & $0.174^{*}$ \\
\hline & & & $(1.996)$ \\
\hline Year dummy variables & YES & YES & YES \\
\hline Industry dummy variables & YES & YES & YES \\
\hline Technology class dummy variables & YES & YES & YES \\
\hline \multirow[t]{2}{*}{ Constant } & $-1.294 * * *$ & $-1.296 * * *$ & $-1.305^{* * *}$ \\
\hline & $(-3.906)$ & $(-3.920)$ & $(-3.940)$ \\
\hline
\end{tabular}




\begin{tabular}{lccc}
\hline Log-likelihood & -8828.68 & -8826.26 & -8826.48 \\
AIC & 17701.35 & 17698.51 & 17700.96 \\
Wald $\chi^{2}$ & 1138.29 & 1151.53 & 1149.68 \\
Prob. $>\chi^{2}$ & 0.00 & 0.00 & 0.00
\end{tabular}

(1) $\mathrm{N}=1795 ;$; (2) t-statistics are reported in parentheses. + if $\mathrm{p}<.10,{ }^{*}$ if $\mathrm{p}<.05 ;{ }^{* *}$ if $\mathrm{p}<.01$; ${ }^{* * *}$ if $\mathrm{p}<.001$ (two-tailed test); (3) Results related to control variables are not shown to save space but are available from authors. 